Mateo, M. (2014). Multilingualism in opera production, reception and translation. Linguistica Antverpiensia, New Series. Themes in Translation Studies, 13, 326-354.

\title{
Multilingualism in opera production, reception and translation
}

\author{
Marta Mateo \\ University of Oviedo, Spain \\ mmateo@uniovi.es
}

Despite the significant presence of multilingualism in both opera production and reception as well as in the context of opera translation, the coexistence of different languages in the world of opera has only sporadically received any research attention, either from musicologists or translation scholars. After a brief discussion of the problematic language issue in the history of opera, this article will examine the multilingualism which marks the genesis of opera texts and many opera productions. Next, it will present different types of multilingualism in opera pieces, with examples of each type. Finally, it will study the relationship between translation and multilingual operas from different standpoints, including a brief analysis of the plurilingual reception context often created by the various translation modalities applied to opera works. A descriptive and contextual approach will mainly be used in this study, which aims to do justice to the presence of multilingualism in the opera house, in both source and target contexts, as well as to encourage further research on this topic within Translation Studies.

\section{The language issue in the study, history and translation of opera}

For historical and artistic reasons, multilingualism has had a significant presence in both opera production and reception as well as in the context of opera translation. However, the coexistence of different languages, which seems to be inherent in the opera experience, has only sporadically received any research attention, from either musicologists or translation scholars. This article will try to fill that gap, since Meylaerts's (2010) claim that "translation and multilingualism are inextricably connected" (p. 227) seems to be particularly true in the world of opera. Rather than involving a substitution of one language for another (very evident in translation when compared to multilingualism [Grutman, 2009, p. 182]), the translating code often actually supplements the source text in opera, producing a plurilingual reception context. But the production of opera texts and performances - in both source and target reception contexts - is also frequently the result of a multilingual environment.

A descriptive and contextual approach will help us observe this phenomenon in its various forms and functions, and the best way to start 
is by briefly considering the thorny language issue in musical drama. Indeed, the history of opera has been marked by the role of language as a communicative and symbolic system, and by the unequal presence of different languages in this hybrid genre. Theoretical studies in musicology, popular debates and criticism of opera pieces and opera in general as well as controversies have surrounded the practice of opera translation in its different modalities.

\subsection{Text and music in opera}

Opera is musical drama, which means that "[m]usic, performance and verbal text all collaborate in the creation of meaning. Nevertheless, the powerful presence of music has traditionally framed the conception of opera as an essentially musical genre, rather than as a dramatic art" (Mateo, 2012, p. 115). Indeed, the fact that the verbal text is sung makes opera a special type of drama (Corse, 1987, p. 12), as a result of the uneasy relationship between language and music which has always marked all types of vocal music. Two conflicting orientations, a textual and a musical one, have repeatedly figured in the debates around song history in the West (Fornäs, 1997, p. 110), attracting - in the case of opera - composers, librettists, opera critics, musicologists and opera buffs. Corse (1987) summarises this preoccupation with language in the world of music: "the debate over whether the text or the music is most important, whether music serves or is served by language, has been a problem since the inception of opera as a self-conscious entity" (p. 11). Other related issues have been whether an opera text should be in prose or poetry, the (lack of) impact of the literary quality of the libretto on the general quality of the opera, and the role of the libretto in the development of opera as a genre (Pauly, 1970, pp. 11-12 and 14; Salzman \& Desi, 2008, p. 84).

Two systems are blended in hybrid genres such as opera through the mediation of the human voice, and different roles and communicative/aesthetic values have traditionally been attached to each of these two separate symbolic codes: briefly, music is interpreted as the affective, emotional system, whereas verbal language would be the intellectual mode, since it is able to name, to convey irony and ambiguity. "Adding a new dimension to speech, [music] brings to the surface what the characters cannot or will not utter. It is a mirror of the unconscious" (Weisstein, 2006/1961, p. 11). However, it cannot name the objects of emotions or thoughts, it cannot "signify", a function reserved for verbal language. Recent studies, however, suggest that the difference between text and music is not as clear-cut as has often been claimed and that "[r]eal meaning is everywhere (in words as well as in music)" (Fornäs, 1997, p. 117). The text-music relationship is therefore problematic ${ }^{1}$ and, at least in opera, the functions attached to each are not so sharply 
distinguished: as Corse (1987, pp. 12-15) explains, although it is true that the aesthetic function lies more in the music than in the text (so that librettos tend to emphasise the communicative function of language), both systems work together, creating meaning and encouraging multiple interpretations; both are symbolic and semiotic (Corse, 1987, p. 151). Indeed, a dialectical conception of the text-music relationship makes it possible to consider why the same text may be set to different musics and, conversely, why the same music may fit in with different words (Ruwet, 2002, pp. 80-81). Fornäs (1997) concludes that "[t]here is music in texts and text in music" so "[t]he text-music dichotomy is an illusion" (pp. $120-121)$.

The relevance of these issues to the study of multilingualism in opera and its translation will hopefully become obvious throughout this article. It is important, however, to point out two aspects right from the start: first, the fact that "meaning" comes not only from the verbal text may explain why the semantic content of words is often ignored by opera-goers, or at least not considered vital to their enjoyment of the opera piece. Many audiences will not fully understand multilingual opera texts, but this has often been the case with most opera receivers attending monolingual productions, either because the sung text is in a foreign language or because of the inevitable distortion created by the singing. For uncomprehending audiences who nevertheless enjoy the operas, the words probably function as music; ${ }^{2}$ as Fornäs (1997, p. 113) remarks, this often happens when people listen to an unknown language. This has been at the heart of many arguments against sung translation and it probably explains the preference for surtitling in many opera houses today. Secondly, the conception of vocal music as a blend between a verbal and a non-verbal mode is also central to recent approaches of a holistic nature to opera translation (e.g., Kaindl, 1995) which consider this type of musical drama as a multidimensional type of art, whose semiotic complexity - the interplay of language, music and vocal and scenic performance - generates the meaning of the operatic text and cannot therefore be disregarded in the study or the actual decision-taking process of translation strategies (see Bosseaux, 2011; Mateo, 2012).

Some studies adopt a more cultural perspective, taking into account the historical, sociological, economic or ideological factors in source and target cultures which explain the why and the how of song translation (not just of operas) (e.g., Bosseaux, 2011 ; Mateo, 2001). An important concern in these studies is the question of which languages are accepted for which musical genres, the language(s) translated into for the different modes of song translation, or how the source language has determined the selection of musical texts to be imported by a target context. This, in turn, ties in with the connections Meylaerts (2006) observes between multilingualism and translation: 
The question of which language(s) can/cannot/must be used necessarily implies: which one(s) can/cannot/must be translated from or into, by whom, in what way, in which geo-temporal, institutional framework etc. This is why translation seems heavily institutionalised in multilingual societies. (p. 2)

These issues have actually occupied a prominent role in the history of opera, making up the other, more practical, aspect of the language issue in relation to opera production and translation.

\subsection{The language of opera(s)}

The question of which language(s) to use in opera texts or productions has had a strong presence in opera history, with some remarkably heated and interesting arguments having been voiced in certain periods and countries. Translation often played a central role in many of these debates and it is closely linked to the development of the genre. Opera's language of origin, Italian, was soon adopted as the main operatic language throughout practically the whole of Europe. As Salzman and Desi relate, during the Hapsburg Empire, Vienna - where Italian was understood and spoken - witnessed a wave of immigration of singers, musicians, composers and even librettists from Italy. From the main AustroHungarian cities they spread to the German States, then to Spain, Portugal, Russia or England, some even crossing the Atlantic. Thus, "Italian became the international language of music" (Salzman \& Desi, 2008 , p. 79), only being resisted in France, a country which could boast a musical drama of its own and could therefore question the supremacy of the Italian genre (Arkus, 2003, p. 4). Audiences elsewhere accepted this. In Spain, for instance, the reception of Italian opera at the end of the 18th century meant the acknowledgement of an international - and probably modern - cultural fact (Álvarez Cañibano, 1995, p. 124). The situation implied that, all around Europe, non-Italian composers would choose Dante's language for their pieces, many of which travelled throughout the continent, being performed by vocal virtuosi such as the castrati (Salzman \& Desi, 2008, p. 88).

The Italianism prevailing in 18th-century opera, which was only resisted by a number of composers and music lovers, neatly illustrates how "[m]any linguistic encounters in the public sphere are clearly framed by a dominant language, restricting other languages to 'spectacular fragments"” (Rampton, 1999, in Androutsopoulos, 2007, p. 225). The supremacy of Italian lasted well into the 19th century (even later in some countries). In Britain, for instance, audiences generally rejected operas sung in English throughout the 18th and 19th centuries and during Queen Victoria's reign works originally composed in French, German, Russian or English had to be turned into Italian in order to be performed at Covent 
Garden (Arkus, 2003, p. 2, p. 9; Gallo, 2006, p. 423). But this monolingualism which reigned in European opera houses also triggered off some strong reactions in various countries, which ran parallel to the historical and political changes taking place from the end of the 18th century. "Just as revolutionaries fought for liberty and national constitutions, composers and librettists strove to express themselves in the music and languages of their homelands" (Gallo, 2006, p. 427). At the end of the baroque period in music, each nation tried to develop its own style (e.g. the English ballad opera, the French drama lirique, the German Singspiele or the Spanish stage tonadillas), while they championed the suitability of their language to musical drama. The famous Querelle des bouffons in France, in which the new Italian comic opera was bitterly fought by the supporters of the traditional French baroque opera of Lully while Jean-Jacques Rousseau defended the use of Italian (see Salzman \& Desi, 2008, p. 88), is a good example of the debates sparked by the question of language in relation to opera, which have continued to the present day.

Other languages, such as German, English, Czech and Russian, gradually joined Italian and French in European opera houses throughout the 19th and early 20th centuries (see Desblache, 2007, pp. 160-161), ${ }^{3}$ and in countries such as Britain and Spain a strong awareness of the need to create a national opera of their own developed (Arkus, 2003, p. 3; Casares Rodicio, 1995, p. 94).

Spain is a case in point illustrating the struggle between Italian monolingualism in opera houses and linguistic protectionism, which was usually encouraged by means of translation (for a detailed discussion, see Mateo, 2001, pp. 33-40). One of the best-known and earliest attempts to impose the local language in opera productions was King Carlos IV's 1799 Royal Order, which forbade all performances (drama, opera, dancing) in a foreign language. According to Álvarez Cañibano (1995, p. 149), this Order simply sanctioned what was already a common practice in Spain. Indeed, many theatres produced operas translated into Spanish, except in Barcelona, which kept a more Italian tendency. The prohibition was lifted in 1821 (Casares Rodicio, 1995, p. 97) and the 19th century staged the tension between the two tendencies, with some important debates and heated speeches even at the Academy of Language and the Academy of Fine Arts (Casares Rodicio, p. 107, p. 117). While certain national productions had to be translated into Italian due to the prevailing Italianism in the country as well as to keep some distance from the more "popular" Spanish zarzuelas, Spain also followed the European trend of making national identities more visible in musical drama and, consequently, Basque, Catalan and Galician were defended as suitable for opera too. ${ }^{4}$ Catalonia developed a special taste for German opera at the turn of the 20th century, and many of Wagner's and Mozart's works saw sung translations into Catalan. For its part, the linguistic protectionism of Spanish continued well into the 20th century, under different political 
regimes. Thus, an Act was passed by the Spanish Republican Government in 1931 imposing Spanish as the singing language for all operas performed at the Teatro Real in Madrid (Mateo, 2001, p. 38); and in Franco's early regime, when the Civil War had not yet ended, a sung translation competition was organised for operas in Italian and German (i.e., the languages of friendly countries) to be turned into Spanish (Medina, 2002).

The tensions which have marked the development of opera in countries such as France, Spain or Britain are particularly interesting to the study of opera translation and, in my view, relevant to the question of multilingualism too. The use of Italian made many audiences around Europe think of opera as a foreign language artistic form. Ironically, the monolingual tendency in the creation or performance of opera texts provoked a multilingual reception context, which has persisted to the present day. Audiences' acceptance of opera productions in a language which was not their own was gradually generalised to whatever the original language of the opera text happened to be, a tendency which became prevalent at various paces depending on the target country and on the source language (see Arkus, 2003, pp. 11-12). The original languages are generally the norm in most opera productions today, particularly in those countries in which opera is considered as "an imported, high-art phenomenon”. As Salzman and Desi (2008) explain,

[t]his has been reinforced by the existence of a standard repertoire dominated by ultra-familiar 'masterpieces' [... and it] has now extended even to works from Eastern European countries whose languages present major challenges to Western performers. (p. 80)

Nevertheless, since opera audiences today mostly expect the source texts to be comprehensible, some mode of translation is required. Moreover, as I explain in section 4 below, today's commonest way of watching opera also creates a multilingual reception context. According to Desblache (2007),

paradoxically for a genre steeped in tradition and often criticised for its highbrow focus, opera is the only artistic form which carries its repertoire in Italian, French, German, Russian and a few other languages, making multilingualism today more visible than in any other creative strand. (p. 161)

\section{Multilingualism in opera production}

The overview above of the problematic role of language and languages in opera texts and history suggests that linguistic issues do not make an appearance only when translation is involved, but that multilingualism 
features prominently in various aspects of this genre. There are several ways, for instance, in which languages can coexist in opera production. Certain composers' work includes pieces in various languages: e.g. Häendel and Mozart had some librettos written in German, others in Italian; Albéniz composed for English, French, Italian and Spanish texts; Gluck's operas are either in French or in Italian. The multilingual cultural dynamics in both present and past contexts, which Meylaerts (2006, p. 5) discusses in her study on heterolingualism and Translation Studies, is well exemplified in opera by Gluck, a German composer from Bohemia who "brought full-blown classicism to France, and classicism flowered, operatically and otherwise, in Vienna - first in Italian but then afterwards also in German" (Salzman \& Desi, 2008, p. 89). Gluck provides an example from the opera context for Meylaerts' (2006) claim that "by definition, discourses are never totally monolingual. [...] the monolingualism of the authors, critics, audiences, etc. in the source and target cultures may be less absolute than conventionally expected" (p. 5).

The plurilingual nature of the opera genre can also be observed in the genesis of opera works, often the result of adaptation from literary pieces originally written in a different language. The journeys made by most texts before they become librettos are extremely complex, frequently crossing linguistic borders and/or literary genres. Consequently, a majority of operas cannot really be said to belong to a particular source culture; rather, they should be described as multiEuropean in essence. One probably has to accept, as Pym (2004) suggests for other types of texts, "that the place of source-text production may be more intercultural, indeed more hybrid, than that of translations" (para. 1: Abstract). Thus, which 'nationality' should be assigned to Verdi's Traviata, Falstaff or Macbeth, to Donizetti's Lucia de Lammermoor, to Bizet's Carmen or Puccini's Bohème? Composers have delved into European literature to find sources for a good libretto: for instance, Verdi frequently resorted to plays by Shakespeare, as well as to works by Schiller and Hugo (Corse, 1987, p. 12). ${ }^{5}$ In his study of "literature as opera", Schmidgall (1977) reports on the great number of operas which have been based on literary masterpieces and the range of literary genres and national literatures they come from. His survey of literary pieces which have been the source of librettos covers, for example, an Italian Renaissance epic romance, a French domestic comedy, a German historical drama, an English romantic-historical novel, a Shakespearean tragedy and a satiric Russian poem (Schmidgall, 1977, p. 22). ${ }^{6}$

Interestingly, according to Pauly (1970), "composers often received the stimulus for writing an opera from seeing rather than reading a play. Puccini saw Madame Butterfly [and] Tosca [...] as plays, in languages that he could hardly understand" (pp. 13-14). Sometimes the musical piece has overtaken the literary source, as has been the case with Richard Strauss's Salomé, whose German libretto was based on Oscar 
Wilde's play, which the writer originally wrote in French and later had translated into English.

The textual production of opera pieces strongly supports Meylaerts's (2010) claim that "every text is a collage of many texts in several languages in an often continuous translation chain" (p. 228). It also illustrates the three contexts of language cohabitation which András Horn (1981, in Stratford, 2008, p. 459) identifies for literature, simultaneously or throughout history; in the case of opera, different languages may coexist: (a) in different works within one country's opera production; (b) in the different works by one and the same composer; and (c) within one and the same libretto presenting a mixture of languages (examples of which will be presented in section 3 below).

Moreover, in the history of opera, it is not unusual for a work to have been composed in one language but to have achieved success in a different one, chosen by the composer to make the piece known to audiences other than that of its first night, and which may then become the opera's usual language on stages throughout the world. Thus, Verdi's Don Carlo was set to a French libretto for its first night in Paris, in 1867; however, after the initial fiasco of this original version, it was the revised Italian version first performed at Milan's La Scala in 1884 that became the most commonly produced one. Wagner's The Mastersingers of Nuremberg had a successful first night in German in Munich, in 1868. It was immediately performed in opera houses all over Europe, either in the original language or in English (in London), Hungarian (in Budapest), French (in Brussels) and Italian (in Milan, but also in Madrid, where Italianism was still strong in 1897 and where Wagner's opera was not performed in its original language until 1926). Many pieces of musical drama therefore not only travelled before their actual genesis as operas, but often soon afterwards. Thus, the coexistence of different languages also marks the general reception of one and the same opera.

Multilingualism can be observed in opera production not only at the textual level, but also in the extratextual context - at an institutional, cultural and even political level. Modern productions are usually plurilingual in terms of the agents involved, since the usual formula in opera houses today is to have singers from different countries, an artistic team which is often foreign too (as productions often travel around), and a permanent local chorus and production team. Consequently, in many opera houses, rehearsals often involve at least two languages, one local and the other foreign, which all or at least some members of the production can understand. The chorus usually has to learn vocal scores in several languages for one and the same season, depending on the original languages of the operas programmed. And opera singers also normally sing in several tongues, generally learning the pieces in the original version or the most commonly used today, which enables them to travel worldwide with the roles they have specialised in. Indeed, the internationalisation of singers is considered by Salzman and Desi (2008) 
as one of the factors which have "contributed to the increasing practice of original language performance" (p. 80), together with the availability of librettos and of audio and video recordings, the spread of international music festivals and the introduction of surtitles, among other reasons.

In the past, the multilingualism which characterises the opera production process was not only in the wings but in the actual performances too:

It was not unusual for operas to be offered half in Italian, half in the language of the country in which they were performed. Often, the arias were sung in Italian while recitatives were sung or spoken in another language. Different roles were sometimes even sung in different languages. This remained relatively common until the mid-twentieth century, as singers often imposed the language in which they sang. (Desblache, 2007, pp. 159-160)

The situation described by Desblache probably shows that the literary message was perceived as secondary to enjoying the beautiful sound of a particular singer's voice. But multilingual performances were sometimes socially or politically motivated: in the early years of the Finnish National Opera (founded in 1873 as the Native Opera), Finnish and Swedish would alternate on its stage for different productions on the same night, so that Swedish-speaking people living in Helsinki could also be won over. In the 1920s, when notable foreign artists had to be engaged to direct it, this company became very cosmopolitan and up to three languages could sometimes be heard on the stage during the same performance (GómezMartínez, 1996, pp. 74-75). Even today, in some opera festivals, an original foreign language is combined with the local one. This was the case, for instance, of a performance of Mozart's Abduction from the Seraglio at Catalonia's summer Festival Peralada in 1997, in which each role was split between two performers: a singer singing the arias in German and an actor performing the dialogues in Catalan, a risky but successful formula devised by the director Mario Gas for this production (Pujol, 1997).

"Opera has long had an intercultural dimension", Susan Bassnett (2000, p. 103) rightly states. In my view, this is clearly reflected in the different ways in which multilingualism materialises in the production process. Less commonly, it is possible to find it in one and the same opera piece.

\section{Multilingualism in opera texts}

According to Grutman (2001, p. 158), there is no objective limit for a (literary) text to be classified as multilingual. Likewise, there also are different degrees to which opera pieces have made use of two or more 
languages, ranging from a few foreign words or phrases inserted in the libretto (corresponding to what Androutsopoulos (2007) calls "minimal or token bilingualism" [p. 214]) to several stanzas in one aria, whole arias or fixed parts of the opera text or performance. Whatever the extent or type of multilingualism, it always seems to be "the outcome of strategic decisions at specific historical moments", as Androutsopoulos (2007, p. 214) has observed for bilingualism in the media. Indeed, as is also the case with songs (see Davies \& Bentahila, 2008, p. 251, p. 259), the mixing of languages in opera librettos usually responds to organisational, aesthetic or characterising purposes and achieves different communicative and stylistic effects.

Three situations can be identified as cases of multilingualism in opera texts. As Davies and Bentahila (2008) suggest for bilingual popular songs, the three cases can be studied

in relation to a number of issues within the performance context, such as what these languages signal about the singer/persona, how they relate to target or potential audiences [...], and how they contribute to the message. (p. 260)

Proceeding from minimal to maximal bi/multilingualism, I shall start with those operas which include the odd word, sentence, stanza or aria in an otherwise monolingual libretto. Of the eight roles Horn attributes to literary heteroglossia (1981, p. 226, in Stratford, 2008, p. 461), four can be selected for opera multilingualism in this first group: contributing to characterisation; enhancing the illusion of reality; producing a comic effect; and functioning as a quotation. Furthermore, like literary writers, librettists and composers often resort to "the cultural and sociolinguistic knowledge they assume they share with their audiences" (Androutsopoulos, 2007, p. 215), in order, for example, to evoke common associations between languages and social identities (sometimes reinforcing cultural stereotypes), establish power relations, signal otherness in a certain character, introduce intertextuality (quoting other operas, songs, prayers, literary works, etc.) to various purposes, or create humour. I have identified the following examples, which illustrate these purposes: ${ }^{7}$

- Orlando Furioso, by A. Vivaldi (libretto by Gr. Braccioli, adapted from Ariosto's romantic epic; first night in Venice, 1727): the libretto is in Italian but contains a few sentences in French in Orlando's famous moment of madness (in Act III, scene V), which seemed to underline the character's insanity.

- $\quad$ Eugene Onegin, by P. I. Tchaikovsky (libretto by K. Shilovski and M. Tchaikovsky, the composer's brother; first night in Moscow, 1879): the libretto is in Russian but there are a few exchanges and couplets in French in Act II, which portray a French character, the singer Monsieur Triquet. 
- The Queen of Spades, by P. I. Tchaikovsky (libretto by M. Tchaikovsky, who based it on a short-story by A. Pushkin; first night in St. Petersbourg, 1890): the libretto is in Russian but there are some lines in French in one aria sung by the Countess (in Act II), reminiscing about her happier youth in Paris, when she had sung before the French aristocracy, including Madame de Pompadour. The Countess quotes a stanza from A. Grétry's opera Richard Coeur-de-Lion, adding realism and highlighting her characterisation.

- Tosca, by G. Puccini (libretto by G. Giacosa and L. Illica, based on V. Sardou's play La Tosca; first night in Rome, 1900): the libretto is in Italian but there is a "Te deum" sung in Latin, which contributes contextual realism to the scene.

- Der Rosenkavalier, by R. Strauss (libretto by H. von Hofmannsthal, in collaboration with $\mathrm{H}$. Kessler; first night in Dresden, 1911): the libretto is in German but there is a stanza in Italian in Act I, for the sake of humour and characterisation, since it is sung by "the Italian tenor" from a vocal score borrowed from Molière's The Bourgeois Gentilhomme (last scene in Act V); thus, this instance of multilingualism introduces intertextuality too.

- Vec Makropulos, by L. Janáček (libretto also by Janáček, based on a play by K. Capek; first night in Brno, 1926): the libretto is in Czech but there are some lines in Spanish and Greek, as the main character, the immortal opera singer Emilia Marty, has assumed many identities over her 300-year life, among them that of a gypsy woman, Eugenia Montez. There are a few sentences in Spanish in Act II, when Emilia refers back to Eugenia. At the end of the opera, in Act III, when she turns out to be Elina Makropulos, the famous soprano dies praying in Greek.

- War and Peace, by S. Prokofiev (libretto by Prokofiev himself in collaboration with his wife M. Mendelssohn-Prokofiev, based on the novel by L. Tolstoi; first night in Moscow, 1959): the libretto is in Russian but there are a few sentences in French in Part I, in order to create light humour (evoking an elegant dance in a ball scene) and, again, to enhance realism and characterisation, as members of the French army, including Napoleon himself, take part in the plot.

The second case of multilingualism in opera texts is directly related to target or potential audiences (see Davies \& Bentahila, 2008, p. 260), for it is the result of the prevailing taste in 18th-century European opera, and illustrates the situation described by Desblache (2007, pp. 159-160) at the end of section 2 in this acticle. As can be expected, most librettos in the 18th century were written in Italian; indeed the majority of them were penned by Pietro Metastasio, ${ }^{8}$ whose texts were set to music by many different composers throughout the century and in various countries. 
However, probably in order to enable audiences to follow the plot more easily and increase their enjoyment of the performance, it became common in some places to perform the recitatives in the local language. This reflects, on the one hand, the different roles assigned to the various sections in Baroque and Classic opera, where "the division into recitative and aria was both textual and musical - prose carried the action forward in recitatives, while poetry served for the more reflective, lyrical and emotional arias" (Pauly, 1970, p. 14). On the other hand, it illustrates the singers' hold over productions, for they could impose the sung language, usually Italian. ${ }^{9}$

The mixing of a dominant language and a less powerful one, or of two indigenous languages, simultaneously coexisting in a particular culture, period or genre had been observed in the lyrics of older periods: for example, in medieval carols which mixed Latin with one or more European vernaculars, or earlier songs in 11th-century Al-Andalus which combined Hebrew, Arabic and Romance languages (Davies \& Bentahila, 2008, p. 248). Bilingual opera performances seem to have been particularly common in 18th-century Britain, where a large number of operas were staged with the Italian aria-English recitative formula. Many composers and librettists were commissioned to adapt Italian operas to this pattern and most of the pieces were extremely popular, as can be inferred from the number of monolingual and bilingual versions, frequently adapted from the same libretto, Metastasio's. Most of them, however, have fallen into oblivion and are no longer performed. Nevertheless, they probably contributed to establishing the tradition of British musical theatre: more than two hundred operas were composed in the 18th century, nearly three hundred in the 19th century (Arkus, 2003, p. 5).

The following English-Italian versions (either of serious operas or of pastiches) have been recorded: ${ }^{10}$

- $\quad$ Artaserse. Genre: pastiche; composers: R. Broschi, J. A. Hasse and N. Porpora; librettist: P. Metastasio (revision by D. Lalli); first night: The Haymarket Theatre, London, 1734; languages: English (recitatives) and Italian (arias); other (non-bilingual) versions: more than 90, mostly forgotten now. There is another bilingual version by T. Giordani and M. Vento (1772) and a fully English one by Th. A. Arne, which was very successful when it was first performed at Covent Garden in 1762.

- Ciro riconosciuto. Genre: serious opera; composer: G. Cocchi; librettist: P. Metastasio; first night: The Haymarket Theatre, London, 1759; languages: English (recitatives) and Italian (arias); other (non-bilingual) versions: around 20, today forgotten.

- Demetrio/Cleonice, queen of Siria. Genre: pastiche; composers: F. Bertoni, B. Galuppi and F. Giardini; librettist: P. Metastasio; first night: The Haymarket Theatre, London, 1763; languages: English 
(recitatives) and Italian (arias); other versions: more than 50, no longer performed - four of them bilingual: the versions by G. B. Lampugnani (1744), G. Cocchi (1757), P. A. Guglielmi (1772), and by A. F. Gresnick (1787).

- Didone abbandonata. Genre: serious opera; composer: V. L. Ciampi; librettist: P. Metastasio; first night: The Haymarket Theatre, London, 1754; languages: English (recitatives) and Italian (arias); other (non-bilingual) versions: more than 70, none of which has survived. There is another bilingual version of this opera, by V. Rauzzini and A. Sacchini (1775).

- $\quad$ Ezio. Genre: serious opera; composer: G. F. Händel; librettist: P. Metastasio (adaptation and translation by $\mathrm{S}$. Humphreys); first night: The Haymarket Theatre, London, 1732; languages: English (recitatives) and Italian (arias). There is another bilingual version, a pastiche, by G. F. Majo, J. Ch. Bach, B. Galuppi, G. B. Pescetti and M. Vento, who worked together to set P. Metastasio's libretto to their own music; first night: The Haymarket Theatre, London, 1764; languages: English (recitatives) and Italian (arias). There are more than 50 versions of Ezio, G. F. Händel's being the only one to survive.

- $\quad$ Issipile. Genre: serious opera; composer: P. Anfossi; librettist: P. Metastasio (revision by A. Andrei); first night: The Haymarket Theatre, London, 1784; languages: English (recitatives) and Italian (arias); other (non-bilingual) versions: more than 20, on the same libretto, also forgotten today. There is another bilingual version, by P. G. Sandoni (1735).

- L'Olimpiade. Genre: serious opera; composer: Th. A. Arne; librettist: P. Metastasio (revision by G. G. Bottarelli); first night: The Haymarket Theatre, London, 1765; languages: English (recitatives) and Italian (arias); other (non-bilingual) versions: more than 50, on the same libretto, none of which have survived.

- $\quad$ Siroe, re di Persia. Genre: serious opera; composer: F. Giardini; librettist: P. Metastasio; first night: The Haymarket Theatre, London, 1763; languages: English (recitatives) and Italian (arias); other (non-bilingual) versions: more than 30, on the same libretto, no longer performed either. There is also a bilingual version by $\mathrm{G}$. B. Lampugnani (1755).

- Zenobia. Genre: serious opera; composer: R. Edgcumbe; librettist: P. Metastasio; first night: The Haymarket Theatre, London, 1800; languages: English (recitatives) and Italian (arias); other (nonbilingual) versions: more than 20, on the same libretto, which have, like practically all the others in this group, fallen into oblivion.

Finally, what I have classified as a third type of multilingualism in opera texts is formed by a mixture of tongues present on more or less equal 
terms in contemporary works, mostly exploiting symbolic rather than referential values. Borrowing Grutman's (2001) description of the role of language switching in modernist poetry and avant-garde writing, these operas "bespeak a growing consciousness of language as a material in and of itself" (p. 160). Language becomes the protagonist, and this goes hand in hand with the increasing importance of fragmented and nonlinear texts which have taken over linear or narrative ones in much modern and postmodern opera (Salzman \& Desi, 2008, p. 89). Each author recreates his/her own world, but this is frequently a world thought of in phonetic terms. Some of these pieces of musical drama are made up of "fragments from various languages, overlaid on one another like palimpsests. [...] In such works, the signification of words and texts may play a role but one not much greater than the value of the texts as pure sound" (Salzman \& Desi, 2008, p. 93).

The following operas from the 20th and 21st centuries are good examples of this type of multilingualism in various ways and degrees: ${ }^{11}$

- Oedipus Rex, an opera-oratorio by I. Stravinsky (libretto by J. Cocteau, who wrote a text in French, based on Sophocles' play; Stravinsky commissioned J. Daniélou to translate it into Latin; first opera performance in Viena, 1928). It is a short two-act opera in which the dramatic parts, in Latin, are complemented by a narration in the audience's language (there are recordings with the narration in French by Cocteau himself, as well as in English, German or Japanese). The language plays a vital part in this opera, having been chosen before the actual story by the composer, who wanted an archaic and sober language, probably for distantiation purposes. Cocteau was not very keen on the idea of having his libretto translated into Latin, and suggested the part of Narrator, who is the only character actually moving on the stage, the other characters behaving like living statues. Schmidgall mentions Stravinsky's piece as an example of equivalence between music, subject and language, and quotes the Russian musician's joy at composing to a language of convention: "The text thus becomes purely phonetic material for the composer" (Schmidgall, 1977, p. 7). ${ }^{12}$

- $\quad$ Babel 46, by X. Montsalvatge (libretto by Montsalvatge himself; first night at the Festival Peralada in Catalonia, 1994, although it had actually been finished in 1964). The libretto is about the day when a number of World War II refugees - two Spaniards, two Italians, two Sephardim, a Scotsman, a Frenchman and two men from Mozambique - leave their refugee camp at the end of the war. The composer makes them all sing in their own language, so the libretto combines Spanish (including the Sephardim's beautiful 15th-century Castilian), Catalan, English, French, Italian and Portuguese, besides a few sentences in Hebrew and German. As in 
a sort of Tower of Babel alluded to in the very title of the opera, the characters, each of whom has their own musical style, constitute a bitter reflection on the difficulty of human relations, particularly in forced coexistence.

- $\quad$ Satyrikon, by B. Maderna (libretto by the composer himself and I. Strasfogel, based on Petronio's piece; first night at Scheveningen, Holland, 1976). It is a one-act piece, made up of sixteen numbers, in which four characters sing, respectively, in English and German, French, a vocalised language with no words, and Latin.

- $\quad$ The Civil Wars: a Tree is Best Measured when it is Down, by Ph. Glass, D. Byrne, G. Bryars, H. P. Kuhn and others. The libretto, inspired by the American Civil War, was mostly written by the conductor Robert Wilson, who worked together with different writers from different languages to create the various versions intended for this opera; the Cologne performance (1984) incorporated passages from Racine and Shakespeare whereas the production for Rome, composed entirely by Philip Glass (1984), combined Latin, Italian and English.

- Akhnaten, also by Ph. Glass (libretto by Glass himself, in collaboration with Sh. Goldman, R. Israel and R. Riddell; first night in Stuttgart, 1984). The librettists used parts of The Book of the Dead as well as documents from Ancient Egypt. The opera combines ancient Egyptian, Akkadian and Hebrew, with a modern language for the narration (English, originally). There is an aria which is meant to be sung in the audience's language.

- Alicia en el País de las Maravillas (Alice in Wonderland), by the Argentinian composer M. Lambertini (libretto by the composer, based on Lewis Carroll's famous novel; first night in Bueno Aires, 1989). The libretto alternates English, Italian, German and Spanish in its different parts (ensembles, duets, recitatives and the narration, which is assigned to Carroll himself, who therefore appears as a character in the text). The composer has described the qualities which she exploited from each language. ${ }^{13}$ Interestingly, she indicates that the Spanish parts can be performed in the language of the audience in non-Spanish speaking countries, but always with a marked English accent. This illustrates the attention a number of musicians pay to the phonetic aspects of language.

- The Cave, by St. Reich (libretto by the composer's wife B. Korot; first night in Vienna, 1993). The libretto, based on interviews with Israelis, Palestinians and USA citizens about the different views on Abraham/Ibrahim's story as reflected in the Bible, the Koran and the Torah, is in English, Arabic and Hebrew.

- El viaje a Simorgh, by J. M. Sánchez-Verdú (libretto by the composer himself, who adapted a novel by Spanish writer Juan Goytisolo and incorporated poems and other texts by San Juan de la Cruz, Ibn al Farid, Fariduddin al-Attar, Leonardo da Vinci and 
Fray Luis de León's Spanish translation of The Song of Solomon; first night in Madrid, 2007). The libretto therefore combines Spanish with Hebrew, Latin and Sufic Arabic.

- Love and other Demons, by the Hungarian composer Peter Eötvös, (libretto by Kornel Hamvai, based on the novel by Gabriel García Márquez; first night at the Glyndebourne Festival, 2008). The libretto is in English, but contains fragments in Spanish, Latin and Yoruba, each used for different purposes/characters: for instance, whereas Latin is used for church ceremonies, Yoruba is the language of the Pagan slaves.

Apart from the tendency towards nonlinear narratives, these pieces clearly show that operas composed in modern times frequently incorporate elements from the visual arts, prefer anonymous protagonists over the heroes or anti-heroes of traditional opera (see Salzman \& Desi, 2008 , p. 89), and rely on a collage of (generally pre-existing) texts from different genres, cultures and languages. In Schmidgall's (1977, pp. 360367) view, ${ }^{14}$ these features are not salutary for the genre, which requires theatrical momentum and human materials rather than conceptual states or ideas. According to Schmidgall (1977), another characteristic of these pieces is "the tendency for language to lose its transparency as a communicative medium and become itself an object of scrutiny" (p. 367). In my opinion, this is particularly conspicuous in multilingual operas in which the mixture of languages is important in itself rather than as a means to enhancing characterisation or realism. In the works included in this third type, composers seem to be aware that the audience will not understand the semantic content of all the different sections in their work, nor may it be necessary that they do so. This constitutes one of the "multiple challenges of multilingualism" (borrowing Stratford's title [2008, p. 457]), since plurilingual texts in general (not just operas) are not necessarily addressed at polyglots (Grutman, 2001, p. 158; Stratford, 2008 , p. 464), and it has obvious implications for translation, as will be seen in section 4.

I will end this section with a remarkable case quoted by Salzman and Desi (2008), in which the effect achieved by words which "do not aspire to meaning" (p. 93) is seen at its most extreme: in Giorgio Battistelli's musical drama piece Experimentum mundi (1981), instead of having characters sing in different languages, the spectator is presented with protagonists who are all mute. Paradoxically for a genre where voice is everything, in this work "the voice is merely one acoustic element among others and subtext is more important that any actual text" (Salzman \& Desi, 2008, p. 94). 


\section{Multilingualism and translation in opera production and reception}

\subsection{Translation and multilingual operas}

The musical drama works which were provided as examples of multilingualism in section 3 can be studied in relation to translation from two different standpoints at a textual level, depending on whether we consider the role of translation in multilingual opera texts before or after they have been created.

It seems useful to borrow Davies and Bentahila's (2008, p. 249) original approach to the study of bilingual popular songs, focusing on the use of translation to create linguistically heterogeneous lyrics, and examine the role translation may have played in the genesis of multilingual librettos. While textual analysis is not the object of this article, it may be interesting to see the way in which the three types of multilingual opera discussed above are connected to translation in this regard.

The texts which exemplify the first type of multilingualism (deriving from the odd foreign-language word, sentence or stanza included in the libretto) are not necessarily based on translation - at least, not beyond the intercultural/interlinguistic transfer which the creation of opera texts, (monolingual ones included) generally seems to involve, as described in section 2. Not even Strauss's Der Rosenkavalier, whose Italian fragment inserted in the German libretto comes from a French play, had to resort to translation, since the tenor's aria was also originally in Italian in Molière's piece. In all other cases quoted in that first group, in which some foreign words or sentences are introduced here and there to various purposes, it is not possible - or it is at least very difficult - to know whether translation was the strategy used to obtain them. In any case, it would probably make very little difference whether these foreign insertions are the result of translation or they are original texts of their own. In Davies and Bentahila's (2008) words, "[a] song which combines elements from two languages may or may not have been constructed via translation. Confronted with such a text, one may be unable to deduce how it was composed in the first place" (pp. 251-252). This type of multilingualism is of greater interest to translation from the second standpoint it may be considered from, that is, how opera translators actually deal with these foreign insertions in otherwise monolingual librettos.

Conversely, translation is clearly involved in the next type of musical drama multilingualism outlined in section 3 of this article. Most of the examples quoted there had originally been composed as fully Italian librettos before they got their recitatives performed in the local language (English, in the productions mentioned above). This performance pattern so popular in 18th-century England and elsewhere in 
Europe reflects one of the commonest and most obvious purposes of interlinguistic transfer, which is to cater for target audiences by making alien texts accessible to them - either fully or, as was the case with these bilingual performances, only partially. Translation functioned as an aid to understanding in the creation of these multilingual productions and, contrary to the first type, it is probably of no great research interest if studied from the other approach (i.e., whether and how they were translated afterwards), since these productions have mostly fallen into oblivion and, in any case, it is hard to believe they would have served as source texts for further translations (e.g., for productions with German recitatives and Italian arias).

Lastly, the genesis of the multilingual opera texts I included in the third group (contemporary works presenting a mixture of tongues) has a mixed relationship with translation. The librettos of some of these operas clearly derive from a source text which was turned into a target text to be set to music (e.g., Stravinsky's Oedipus Rex, Lambertini's Alicia en el País de las Maravillas or Eötvös's Love and other Demons); others do not seem to have involved translation - at least so evidently - in their origin (Montsalvatge's Babel 46, the joint composition The Civil Wars ..., or Reich's The Cave), while a number of them may have it partially (Maderna's Satyrikon, Glass's Akhnaten or Sánchez-Verdú's El viaje a Simorgh). Like the first group of multilingual musical works, these operas invite further research from the point of view of how translators of these works have coped with the coexistence of different languages in the librettos.

Indeed, the commoner approach for a textual analysis of translation in relation to multilingual operas would probably be to focus on the strategies translators/surtitlers usually take or can take when dealing with this complex linguistic feature which marks the musical pieces discussed here to various degrees. A descriptive study of the translation strategies that have been used for the operas included in section 3 is, again, not the purpose of the present article. However, it might be useful to examine here the lines that could be followed, and the factors that would have to be considered, in this type of analysis.

The following questions may be asked: considering there are different modes in the translation of musical texts, do the authors of target texts of one and the same multilingual opera for each mode deal with this feature differently? More specifically, what strategies are or can be adopted when the target text is meant for publication as a bi/multi-lingual printed libretto, or as a vocal score? What if it is to be included in a CD insert - for example, can different textual strategies be observed for multilingualism in the different language versions of one and the same $\mathrm{CD}$ ? What if the translated libretto is actually meant to be sung to a target audience? And how is multilingualism usually tackled in surtitling? Will that depend on the languages which are heard on stage? For instance, what happens when the (or a) "foreign" language inserted in the libretto is 
precisely the new audience's mother tongue? ${ }^{15}$ In short, does multilingualism (fully or partially) disappear in (whatever mode of) translation? And what is the effect of the different strategies on the various types of receiver? At another level, considering there are different types of multilingualism (see section 3), are different strategies usually adopted depending on the degree to which two or more languages coexist in the same libretto (i.e., can a divergent general strategy be observed between the translation of operas in the first group and those of the third one)? And is the function of the foreign fragment(s) maintained or changed in the target opera?

In addition, several factors will undoubtedly intervene in the analysis. They are likely to be a combination of, on the one hand, aspects which are specific to each mode of translation and will imply different constraints when dealing with multilingualism in opera texts, and, on the other, those which affect the translation of plurilingual texts in general. Stratford (2008) claims about the latter: "les problèmes de traduction ainsi que les stratégies pour les résoudre vont dépendre des fonctions et des formes du multilinguisme dans l'original" (p. 461). It is possible to observe a number of precise functions in the foreign fragments inserted in the operas I included in the first group above, whereas the effect intended by the mixture of languages in those of the third group is more difficult to establish, being more complex and affecting the whole work, not just a character or a scene as in the former case. As regards the form, one initial distinction that should be made is whether the linguistic heterogeneity is found in a sung part or in a recitative or a spoken speech of the opera, for the constraints on translation will certainly be different. The extent of the alien fragment in the libretto - a few words, a whole aria, several parts or some scenes - will obviously also have a bearing on the translator's decision-taking process.

The technical constraints on translation strategies can be said to be the same for plurilingual operas as for monolingual ones (see Bosseaux 2011 and Mateo 2012 for two general overviews on translation and music and what each translation modality entails in the decision-taking process). Nevertheless, in those cases in which the source text and the translation are simultaneously accessible to target receivers, as happens in surtitling or in bi/pluri-lingual printed librettos and $\mathrm{CD}$ inserts, the language switching which can be heard on the stage or seen in the source text of the publications may be noticed by the corresponding target receivers, who will be aware of a discrepancy should the translator decide to produce a linguistically homogeous target version. Interestingly, however, at least in the case of surtitling, translators can actually exploit this simultaneous access to both texts in the target-context reception and rely on the aural channel for the effect of multilingualism and on the written one for the conveyance of semantic meaning: that is, the pragmatic function of the multilingual fragment(s) could come from the source text heard on the stage performance, whose actual content would be made clear to the 
uncomprehending audiences through the target text on the screen, in which the code-switch may have disappeared. This is connected to the non-autonomous nature of surtitles, whose function is "to communicate with other symbolic modes used in the performance for creating meaning" (Virkkunen, 2004, p. 93), a feature which is therefore not always a negative one for translation decisions. In any case, this will depend on the languages involved and whether the heterolingual fragment belongs to a sung or a spoken part, for not always will target audiences be aware of a language switch in the text performed, not just because of their lack of familiarity with the sound of the foreign language(s) inserted but because of the inevitable distortion which singing exerts on the verbal text.

The reception context is therefore vital in translation decisions for multilingualism in opera texts (as for translation in general, for that matter): "foreign" elements do not have the same connotations in all cultures (Stratford, 2008, p. 463), and the type of reception of the vocal text is a crucial factor too - watching versus listening versus reading, or a combination of two of these modes. Another reception factor which may be considered in translation intended for opera performances is whether the opera house in question is chiefly attended by monolingual operagoers or is characterised by a multilingual international audience (e.g. the Metropolitan Opera House or Covent Garden, although opera houses are becoming more and more multilingual in general). In addition, some theatres offer a choice of languages for their surtitles and most CD inserts also include more than one target text. Thus, yet another factor may be the coexistence of different versions afforded to the receivers of translated operas in some translation modes, which may exert some influence on the strategies chosen for each target text regarding the multilingualism of the libretto.

Therefore, "a holistic and multimodal analysis of the ST is required", taking all the codes which make up the text and the context into consideration (Bosseaux, 2011, p. 193), not just in song translation as a whole but also when confronting a case of multilingualism in it. The process of translating multilingual operas will be determined by general factors such as the possibilities and constraints presented by the other semiotic codes in the performance, the importance of non-verbal information in theatrical texts, the commanding presence of the music in opera, the type of translation reception (given by the mode of translation chosen for the opera text) and, more specifically, how important it is to understand the semantic content of the foreign elements in the opera in order to grasp their communicative value. Regarding the comprehension issue, Davies and Bentahila's (2008) following statement is relevant here, too:

ensuring the audience's understanding of a text does not seem so crucial in the case of song lyrics, since comprehension of the 
words is not the only or even perhaps the most important aspect of the song's impact on the audience. (p. 250)

This may explain why opera has traditionally been a foreign but enjoyable experience to many audiences. In fact, this common situation has probably affected the conception of opera as a purely musical genre until very recently (see section 1 above). With the arrival of surtitling, however, audiences' expectations towards their operatic experience have changed and the conception of opera seems to be recapturing its original essence as musical drama (see Desblache, 2007; Mateo, 2007).

The multimodal analysis of multilingualism in the source opera text should go hand in hand with a functional and creative translation process, as Franzon recommends for the translation of musicals in general (2005, p. 267 , p. 275 ; my emphasis). This is probably the only way to recreate the "strangeness" of the multilingual piece, to use Stratford's (2008, p. 468) term for these works. ${ }^{16}$ The translator should be aware of the fact that the effects of bi/multilingualism may change considerably from culture to culture and that some audiences may be more willing to accept it than others; so the impact of multilingual musical texts "will depend as much on the identity, attitudes and expectations of the listeners as on the careful strategies of their creators" (Davies \& Bentahila, 2008, p. 261, p. 267). According to Grutman (2009), some researchers on multilingualism in literary translation think it is most often left untranslated, as opposed to what happens to the main text containing it; others, however, are of the opinion that "most translators will rather reduce the interlingual tension found in the original" (p. 184). It remains to be seen what actually happens to multilingual operas in translation, a subject I intend to pursue in future research.

\subsection{Multilingualism in the reception of translated opera}

Interestingly, the translation of opera often implies a plurilingual reception context. This article will therefore end with a brief review of how multilingualism, understood now in a contextual sense, is often the result of the translation modes (sung translation or surtitling) chosen for musical texts.

The written versions of opera texts are generally presented in more than one language simultaneously. Vocal scores, particularly if the source language is not a Western European one, are often bilingual (the two languages appearing, one above the other, along with the music stave); they commonly include the original language of the libretto and that of the publishing house's country: for example, Edition Peters usually includes a German or an English target version, Casa Ricordi an Italian one, and Kalmus Music Publishers provide an English translation. In the past, dual-language librettos - which would be purchased before, and 
read during, the performance - became the standard editions, when noted singers started to travel around with original-language productions (Gallo, 2006 , p. 423). Today, opera-listeners are used to finding versions of the libretto in different languages in CD inserts or on the web.

At the opera house, except for sung translated versions (in which one can safely say that translation involves replacing the original language with that of the target audience), the mode of translation most frequently chosen today - surtitling - creates a multilingual product, since the translation on the screen coexists with the source language version sung on the stage. As is the case with film subtitling, two languages are present, in different channels of communication, throughout the reception process, as codes of the source and the target text respectively. Susan Bassnett (2000) observes that the arrival of surtitling in the 1980s has implied "a shift back to audience reading" (pp. 96-97), a type of reception which had disappeared when a black-out was introduced in the auditorium from the mid-19th century onwards, preventing audiences from reading printed librettos during the performance and encouraging sung translation in some European opera houses in the first half of the 20th century (Desblache, 2007, p. 163). The two types of written version are certainly very different, for printed librettos are usually very literal translations whereas surtitles can only provide condensed versions of the original sung text, due to technical, space and time constraints; nevertheless, "it is significant that the surtitle continues the practice of reading that held sway for so long with opera-going audiences" (Bassnett, 2000, p. 97).

The new form of multilingualism created in opera reception by surtitling has replaced a former type in the theatre house, when it was also common in many countries to have an audience who did not speak or even understand the language sung on the stage but willingly accepted the situation, sometimes actually rejecting a sung version in the local language (Mateo, 2001). Non-translation meant the "foreignisation" of the genre and the exclusion of spectators with less refined tastes, who could not enjoy the opera in the source language. The multilingualism created through the use of surtitling seems more inclusive; it has attracted new social groups to opera performances, considerably increased the size of audiences, broadened companies' repertoires and introduced a greater variety of languages in them, since "languages other than Italian, French or German are now more frequently heard in opera houses" (Mateo, 2007, p. 141; see also Desblache, 2007). Moreover, responding to the heterolingual nature of today's audiences and/or to political issues of national identity, some theatres (e.g., the Metropolitan Opera House or Barcelona's Liceu) now offer surtitles in several languages for the operagoer to choose from, thus increasing the multilingualism of the overall reception (and production) process. ${ }^{17}$ Audio description has also recently added another comprehension aid, multiplying the complexity of (interor intralinguistic) versions of one and the same text in the opera house. 


\section{Conclusion}

Multilingualism can be understood as a textual or a contextual feature, particularly in complex semiotic artistic products like opera and drama. In this study, the contextual sense has become more evident, for the coexistence of different languages in opera is more visible in the genesis of opera texts and in their reception (often as a result of the mode of translation chosen), rather than in the opera pieces themselves. There are, however, multilingual operas in the history of opera, and different types have been identified in this article, depending on the degree and the role of multilingualism in them. Regarding the latter, some of the musical dramas illustrate multilingualism as a result of the aesthetic values of the time, while in others - for instance the contemporary examples - it functions as a reflection of - and on - the complex multicultural world we live in. The presence of several languages has been a constant feature in opera reception, either because the works were performed in a language other than that of the audience or, more recently, because surtitling allows the source text to still be accessible to audiences through the singing on the stage. Interlinguistic mediation is more visible with this comprehension aid than in sung translation, making audiences more aware of the need for translation for the full enjoyment of this musical genre. ${ }^{18}$ And opera-goers have undoubtedly now become used to this bilingual reception of performances.

My aim in this article has been to relate translation and multilingualism in the context of opera, looking at the different forms and functions which heteroglossia can take in these artistic texts and contexts, the reasons for its presence in the musical theatre world - certainly different from those of other bi/multilingual lyrics - and the ways in which it may be analysed in terms of translation.

The study of multilingualism within opera translation undoubtedly has the potential to shed light on issues of interlinguistic-intercultural transfer, supporting Meylaerts's (2006) claim that "translation cannot merely be defined as an act of substitution between completely independent and self-sufficient languages, literatures and texts" (p. 10). Further research could focus on the textual translation strategies generally used for cases of multilingualism in opera in the different modes of transfer, or on various reception aspects: for instance, how opera audiences (which are increasingly multilingual) react to the presence of different languages in one and the same opera text in source versus target contexts - although what the "source" culture and the "source" audiences of a multilingual opera might be is often difficult to establish; so those contexts for comparison might better be rephrased as "with or without the 
mediation of translation in the reception of a multilingual opera production".

\section{References}

Alvarez Cañibano, A. (1995). Teatros y Música escénica: Del antiguo régimen al estado burgués. In E. Casares Rodicio \& C. Alonso Gonzalez (Eds.), La música española en el siglo XIX (pp. 123-160). Oviedo: Servicio de Publicaciones de la Universidad de Oviedo.

Androutsopoulos, J. (2007). Bilingualism in the mass media and on the internet. In M. Heller (Ed.), Bilingualism: A social approach (pp. 207-230). London: Palgrave Macmillan.

Arkus, M. (2003). La ópera británica entre Purcell y Britten, o arreglemos el teléfono. Filomúsica. Revista mensual de publicación en Internet, 37, 1-14, and 38, 111.

Bassnett, S. (2000). Theatre and opera. In P. France (Ed.) Oxford guide to literature in English translation (pp. 96-103). Oxford: Oxford University Press.

Bosseaux, C. (2011). The translation of song. In K. Malmkjaer \& K. Windle (Eds.), The Oxford handbook of translation studies (pp. 183-197). Oxford: Oxford University Press.

Carreira, X. (1987). El nacionalismo operístico en Galicia. Revista de Musicología X, 2, 667-683.

Casares Rodicio, E. (1995). La Música del siglo XIX español: Conceptos fundamentales. In E. Casares Rodicio \& C. Alonso Gonzalez (Eds.), La música española en el siglo XIX (pp. 13-122). Oviedo: Servicio de Publicaciones de la Universidad de Oviedo.

Corse, S. (1987). Opera and the uses of language: Mozart, Verdi, and Britten. Rutherford: Associated University Press.

Davies, E. E., \& Bentahila, A. (2008). Translation and code-switching in the lyrics of bilingual popular songs. The Translator, 14(2), 247-272

Desblache, L. (2007). Music to my ears, but words to my eyes?: Text, opera and their audiences. Linguistica Antverpiensia 6/2007: A tool for social integration?: Audiovisual translation from different angles, 155-170.

Fornäs, J. (1997). Text and music revisited. Theory, Culture \& Society, 14(3), 109123.

Franzon, J. (2005). Musical comedy translation: Fidelity and format in the Scandinavian My Fair Lady. In D. Gorlée (Ed.), Song and significance: Virtues and vices of vocal translation (pp. 263-298). Amsterdam: Rodopi.

Gómez-Martínez, M. A. (1996). La nueva ópera nacional finlandesa en Helsinki. In A. Iglesias (Ed.), El Teatro Real de Madrid: Teatro de la Ópera (pp. 73-82). Madrid: Editorial Complutense.

Gallo, D. (2006). Opera, oratorio, song. In P. France \& K. Haynes (Eds.), The Oxford history of literary translation in English, vol. 4 1790-1900 (pp. 420-429). Oxford: Oxford University Press. 
Grutman, R. (2001 [1998]). Multilingualism and translation. In M. Baker \& K. Malmkjaer (Eds.), Routledge encyclopedia of translation studies (pp. 157160). London: Routledge.

Grutman, R. (2009). Multilingualism. In M. Baker \& G. Saldana (Eds.), Routledge encyclopedia of translation studies (pp. 182-185). London: Routledge.

Kaindl, K. (1995). Die Oper als Textgestalt: Perspektiven einer interdisziplinären Übersetzungswissenschaft. Tübingen: Stauffenburg.

Kramer, L. (1999). Beyond words and music: An essay on songfulness. In W. Bernhart, S. P. Scher, \& W. Wolf (Eds.), Word and music studies: Defining the field (pp. 303-319). Rodopi: Amsterdam.

Mateo, M. (2001). Performing musical texts in a target language: The case of Spain. Across Languages and Cultures, 2(1), 31-50.

Mateo, M. (2007). Surtitling today: New uses, attitudes and developments. Linguistica Antverpiensia 6/2007: A tool for social integration?: Audiovisual translation from different angles, 135-154.

Mateo, M. (2012) Music and translation. In Y. Gambier \& L. van Doorslaer (Eds.), Handbook of translation studies vol. 3 (pp. 115-121). Amsterdam: John Benjamins.

Medina, A. (2002). Itinerarios de la ópera española desde la Guerra Civil. In E. Casares Rodicio \& A. Torrente (Eds.), La ópera en España e Hispanoamérica: Una creación propia vol II (pp. 373-392). Madrid: Instituto Complutense de Ciencias Musicales.

Meylaerts, R. (2006). Heterolingualism in/and translation: How legimitate are the Other and his/her language? An introduction. Target, 18(1), 1-15.

Meylaerts, R. (2010). Multilingualism and translation. In Y. Gambier \& L. van Doorslaer (Eds.), Handbook of translation studies vol. 1 (pp. 227-230). Amsterdam: John Benjamins.

Pauly, R. G. (1970). Music and the theatre: An introduction to opera. Englewood Cliffs, N. J.: Prentice-Hall.

Pujol, X. (1997). Suave, que es verano. El País, at: http://elpais.com/diario/1997/08/03/cultura/ (last consulted on 18 April 2013).

Pym, A. (2004). On the pragmatics of translating multilingual texts. JoSTrans. The Journal of Specialised Translation 1/ 2004. Revised version, available at: http://www.jostrans.org/issue01/art_pym.php (last accessed on 7 November 2014).

Ruwet, N. (2002). Función de la palabra en la música vocal. In C. Abbate, L. Chang, R. Dalmonte, L. Kramer, J. J. Nattiez, \& N. Ruwet (Eds.), Música y literatura: Estudios comparativos y semiológicos (pp. 63-92). (Introduction, compilation of texts and bibliography by Silvia Alonso). Madrid: Arco Libros.

Salzman, E., \& Desi, T. (2008). Text. In E. Salzman \& Th. Desi (Eds.), The new music theater: Seeing the voice, hearing the body (pp. 78-95). New York, NY: Oxford University Press.

Schmidgall, G. (1977). Literature and opera: Afterword: The crisis of modern opera. In G. Schmidgall (Ed.), Literature as opera (pp. 3-28; 359-370). New York, NY: Oxford University Press. 
Stratford, M. (2008). Au tour de Babel!: Les défis multiples du multilingualisme. Meta, 53(3), 457-470.

Virkkunen, R. (2004). The source text of opera surtitles. Meta, 49(1), 89-97.

Weisstein, U. The Libretto as Literature (1961); Introduction to the essence of opera (1964). In W. Bernhart (Ed.) (2006). Word and music studies: Selected essays on opera by Ulrich Weisstein (pp. 3-42). Amsterdam: Rodopi.

\section{Operas cited}

Akhnaten, by Ph. Glass, 1984.

Alicia en el País de las Maravillas, by M. Lambertini, 1989.

Artaserse, by R. Broschi, J. A. Hasse and N. Porpora, 1734.

Babel 46, by X. Montsalvatge, 1994.

Ciro riconosciuto, by G. Cocchi, 1759.

Demetrio / Cleonice, queen of Siria, by F. Bertoni, B. Galuppi and F. Giardini, 1763.

Der Rosenkavalier, by R. Strauss, 1911.

Didone abbandonata, by V. L. Ciampi, 1754.

El viaje a Simorgh, by J. M. Sánchez-Verdú, 2007.

Eugene Onegin, by P. I. Tchaikovsky, 1879.

Ezio, by G. F. Händel, 1732.

Issipile, by P. Anfossi, 1784.

L'Olimpiade by Th. A. Arne, 1765.

Love and other Demons, by Peter Eötvös, 2008.

Oedipus Rex, by I. Stravinsky, 1928.

Orlando Furioso, by A. Vivaldi, 1727.

Satyrikon, by B. Maderna, 1976.

Siroe, re di Persia, by F. Giardini, 1763.

The Cave, by St. Reich, 1993.

The Civil Wars: a Tree is Best Measured when it is Down, by Ph. Glass, D. Byrne, G. Bryars, H. P. Kuhn et al., 1984.

The Queen of Spades, by P. I. Tchaikovsky, 1890.

Tosca, by G. Puccini, 1900.

Vec Makropulos, by L. Janáček, 1926.

War and Peace, by S. Prokofiev, 1959.

Zenobia, by R. Edgcumbe, 1800.

1 "Verbal expressions are not so completely discursive as is often believed. [...] Words have presentational as well as discursive aspects - as does, in fact, music! [...] Conversely, music 
(like other non-verbal modes) does not completely lack signification or even discursivity. [...] Melodic, harmonic and formal elements in music often combine in discursive ways and semantically carry associations to extra-musical experiences or objects" (Fornäs, 1997, p. 117). For her part, Corse (1987) believes that this relationship cannot even be reduced to a simple question of complementarity: "Words and music feed upon each other, the music sometimes reinforcing the understanding we have of the text, sometimes supplementing or substituting for it, and sometimes contradicting it" (p. 150).

2 This seems to be connected to the very essence of song: "[s]ongfulness is a fusion of vocal and musical utterance judged to be both pleasurable and suitably independent of verbal content" (Kramer, 1999, pp. 305-306).

3 " $[\mathrm{A}] \mathrm{n}$ opera in a certain language was becoming a statement of identity, and complying with dominant languages often implied betrayal" (Desblache, 2007, p. 161).

4 The first opera performed in Catalan was Lo desengany by Baratta, produced at Barcelona's Liceu in 1885; while Txanton Piperri, by Buenaventura Zapirain, is considered the first Basque opera, received by an enthusiastic audience on its first night in Bilbao in 1899 (Casares Rodicio, 1995, pp. 112, 121-122). Two seminal pieces in the development of opera in Galician are Eduardo Rodríguez-Losada's O Mariscal, which opened in Vigo in 1929, and ;Ultreya!, which had its first night in Madrid in 1935 (Carreira, 1987, p. 675, pp. 678679).

5 Interestingly, Verdi - as well as Britten - "have sometimes chosen subjects for their operas in which language itself figures heavily, subjects in which the way humans use and respond to language becomes an issue in the drama itself" (Corse, 1987, pp. 11-12).

6 As regards the mediation between the two art forms, literature and opera, some composers (Gluck, Mussorgsky, Britten) seem to be more receptive "to literary or linguistic 'domination'”, while others are less so (Mozart, Berlioz, Strauss), according to Schmidgall (1977, p. 13). As regards contemporary opera, he thinks it "ignores the literary creations of our time" (Schmidgall, 1977, p. 369).

7 Carreira (1987, p. 669) reports a zarzuela by Marcial del Adalid, Pedro Maruga (1897), which could be included in this group, for the peasants' choruses in this Spanish libretto are performed in Galician, clearly for the sake of social characterisation as well as to create a realistic atmosphere. This piece eventually became an opera with an Italian libretto, Ines $e$ Bianca, which kept some of the themes from Galician folklore.

8 Metastasio was the Austrian Emperor's official poet and he exerted an important influence on opera composers of the time. 
9 Indeed, arias from other operas would sometimes be inserted in a particular performance for the greater glory of celebrated singers. This gave rise to the pastiche genre: operas made up of a medley of arias and other elements from different pieces, sometimes in various languages or styles, and often without much coherence.

10 I have drawn the information for these entries from the following webpages:

http://es.wikipedia.org/wiki/Categor\%C3\%ADa:\%C3\%93peras_en_italiano http://es.wikipedia.org/wiki/Categor\%C3\%ADa:\%C3\%93peras_en_varios_idiomas (last consulted on 20 April 2013).

The information included on the separate webpage of each opera is said to come from: Bucciarelli, M. (2006). Italian Opera in Central Europe, Berlin: Berliner Wissenschafts; Bucciarelli, M. \& B. Joncus (2007). Music as Social and Cultural Practice, Woodbridge: Boydell Press; Pascual, J. (2004). Guía Universal de la Música Clásica, Teià, Barcelona: Ma non troppo; Price, C. A. (1995). Italian Opera in Late Eighteenth-century London. Oxford: Oxford University Press; and Sadie, St. \& J. Tyrrell (2001) New Grove Dictionary of Music and Musicians, 2nd ed., London: Macmillan.

11 Much of the information initially used to expand this list, as well as a great part of the data for each opera, comes from the general and individual webpages provided at: http://es.wikipedia.org/wiki/Categor\%C3\%ADa:\%C3\%93peras_en_varios_idiomas (last consulted on 20 April 2013). I have also consulted: Gammond, P. (1988). Guía ilustrada de compositores de ópera (translated by Giovanni Mion). Madrid: Mondadori; and Pascual, J. (2004). Guía Universal de la Música Clásica. Teià, Barcelona: Ma non troppo.

12 Stravinsky's choice of a dead language was followed, later in the 20th century, by Philip Glass in his opera about Gandhi's early life in Africa, Satyagraha (first night in Rotterdam, 1980), for whose libretto the American composer chose Sanskrit (Salzman \& Desi, 2008, p. $81)$.

13 "Del inglés exploto las posibilidades musicales de la prosa carrolliana, su ritmo, sus sonoridades, sus juegos fonéticos y semánticos. El italiano, utilizado en recitativos según el modelo mozartiano y en madrigales de corte renacentista, recrea todo un mundo gestual fuertemente enlazado con el género. El castellano, ligado entrañablemente con el aspecto narrativo en los países de habla hispana, otorga mayor verosimilitud al hecho de 'contar un cuento" (http://www.sohns-musica.com.ar/lambertini.html, last consulted on 25 April 2013). 
14 "Opera is essentially an inflationary and elevating art form [...] It is difficult to imagine a theatrically engaging opera that would issue from drama focusing on the tedium and purposelessness of existence" (Schmidgall, 1977, p. 360, p. 362).

15 This thorny problem affects the translation of multilingualism in general. In these cases, "l'importance de la fonction de l'élément étranger déterminerait si on doit ou non le reproduire dans la traduction" (Schogt, 1988, in Stratford, 2008, p. 463).

16 "Un texte multilingue est non seulement 'étranger' mais aussi 'étrange', et sa traduction devrait être à son image" (Stratford, 2008, p. 468).

17 Intralingual surtitles have also become common in some places, and "captioning" or surtitles for the deaf and hard-of-hearing are frequently offered for spoken drama in some important theatre houses, such as the Barbican Theatre in London, where, interestingly, monolingual productions with English captions for English performances seem to attract foreign visitors, thus creating a wider multilingual audience, who uses the surtitles as interlinguistic aids.

18 Curiously, however, surtitlers and surtitling are still rather "invisible" in many respects (e.g. in production reviews; see also Desblache, 2007, pp. 164-166). 